\title{
OS DIREITOS HUMANOS NA DEMOCRACIA COSMOPOLITA SEGUNDO HABERMAS
}

\author{
Aylton Barbieri Durão ${ }^{1}$ \\ Universidade Federal de Santa Catarina (UFSC) \\ (D) https://orcid.org/0000-0002-8264-0620
}

RESUMO:

A propósito da comemoração do bicentenário da obra de Kant Rumo à paz perpétua, Habermas apresenta uma proposta de reconstrução discursiva do cosmopolitismo que contesta a renovação das objeções realistas de Carl Schmitt, segundo a qual só o retorno ao jus publicum Europaeum possibilita a limitação das guerras, enquanto o universalismo moral, conduziu a uma confusão dos valores do político (amigo/inimigo) com os da moral (bem/mal) e serviu de fundamento para que a organização cosmopolita transformasse os interesses particulares de uma das partes em valores universais da humanidade e os negasse a outra parte, provocando a criminalização do inimigo e originando as guerras totais. Contudo, Habermas observa que este fundamentalismo dos direitos humanos somente pode ser evitado por uma reconstrução discursiva que mostra que os direitos humanos não são direitos morais e que a formação de uma democracia cosmopolita, é a única capaz de permitir uma aplicação procedimental dos direitos humanos.

PALAVRAS-CHAVE: Cosmopolitismo; Direitos humanos; Moral; Habermas; Carl Schmitt.

\section{HUMAN RIGHTS IN THE COSMOPOLITAN DEMOCRACY ACCORDING TO HABERMAS}

\begin{abstract}
:
The purpose of the commemoration of the bicentenary of the work of Kant Toward Perpetual Peace, Habermas proposes a discursive reconstruction of cosmopolitanism challenging the renewal of realistic objections of Carl Schmitt, whereby only the return to the jus publicum Europaeum enables limitation wars while the moral universalism, led to a confusion of values the political (friend/enemy) with the moral (good/bad) and served as the basis for the cosmopolitan organization transformed the particular interests of a party to the universal values of humanity and deny the other party, causing the criminalization of the enemy and causing the total wars. However, Habermas notes that this fundamentalism of human rights can only be avoided by a discursive reconstruction shows that human rights are not moral rights and that the formation of a cosmopolitan democracy is the only one capable of allowing a procedural application of human rights.
\end{abstract}

KEY WORDS: Cosmopolitanism; Human rights; Moral; Habermas; Carl Schmitt. Introdução

\footnotetext{
${ }^{1}$ Doutor em filosofia e professor da Universidade Federal de Santa Catarina
} 
Em 1995, Habermas publica um artigo intitulado "A ideia kantiana da paz perpétua a partir da distância histórica de 200 anos", incorporado, posteriormente, a seu livro A inclusão do outro, como parte da comemoração do bicentenário do opúsculo de Kant Rumo à paz perpétua Neste estudo, ele almeja mostrar a necessidade da formação de uma democracia cosmopolita capaz de garantir uma aplicação imparcial dos direitos humanos.

Para isto, ele recorre, inicialmente, a uma reconstrução do projeto kantiano de paz no qual mostra que, como Kant estava situado em um momento histórico dominado pelo equilíbrio das potências europeias, inaugurado pela Paz de Vestfália de 1648 (HABERMAS, 1997, p.194), então, o filósofo de Königsberg dispunha apenas de um conceito de guerra limitada, desconhecendo a guerra total que surgiu com a I Guerra Mundial, por isso, apresentou um conceito negativo de paz, tão limitado como o seu próprio conceito de guerra, começando com uma versão forte do cosmopolitismo na década de 1780, segundo a qual os estados membros deveriam se submeter a uma constituição republicana cosmopolita capaz de exercer coação, mas terminou com uma versão fraca do cosmopolitismo de acordo com a qual os estados soberanos deveriam apenas se reunir em uma associação permanente, mas dissolúvel, a ser implementada pelo mecanismo da natureza narrado pela história a priori, com base na ideia da razão dotada de indubitável realidade prática, de que a humanidade se aproximará constantemente, sem nunca alcançar, os desígnios do cosmopolitismo. Kant considerava que a pacificação das relações internacionais ocorreria em virtude da consecução de três fatores, os quais, segundo Habermas, experimentaram uma espécie de dialética no decorrer do tempo, pois, se a princípio foram desmentidos, posteriormente, eles se realizaram, ao menos parcialmente: a republicanização dos estados soberanos, a força pacifista do comércio mundial e o desenvolvimento de uma opinião pública planetária (HABERMAS, 1997, p.199).

Consequentemente, os acontecimentos históricos contemporâneos, notadamente o desenvolvimento da guerra total no século XX, implicaram a necessidade da formação de uma organização cosmopolita capaz de regular as relações internacionais, mas demandaram a reconstrução comunicativa do projeto kantiano de paz (HABERMAS, 1997, p.208), por isso, ele propõe uma reformulação da ONU como uma organização supraestatal, baseada em uma cidadania e uma esfera pública mundial, capaz de estabelecer uma legislação obrigatória para os estados membros, dotada de poder coativo, bem como do Tribunal Internacional de Haia, habilitando-o para julgar os estados acusados de violarem os direitos fundamentais de seus habitantes.

Por outro lado, na medida em que a sua reconstrução discursiva do cosmopolitismo tem como base o projeto kantiano de paz, Habermas precisa afastar a suspeita de que ela estaria sujeita às objeções contra o universalismo moral que, desde Hegel, têm sido constantemente renovadas 
contra as teorias de viés kantiano. Por isso, ele termina o artigo defendendo o universalismo moral contra o realismo político e o relativismo moral, no qual mostra como o cosmopolitismo reconstruído comunicativamente, embora esteja relacionado com o universalismo moral, não implica, como recordou o realismo político de Carl Schmitt, em uma confusão entre as esferas de valor próprias do político (o par de valores amigo/inimigo) com os da moral (bem/mal), o que resultou na moralização da política e ocasionou a substituição das guerras limitadas entre estados soberanos, típicas do equilíbrio entre as potências europeias antes da I Guerra Mundial, pela guerra total, na medida em que engendrou a associação do inimigo como o mal $^{2}$, relacionando-o também com o relativismo moral, para quem o universalismo moral não passa de uma imposição hipócrita dos valores específicos da civilização ocidental em sociedades regidas por outros valores (HABERMAS, 1997, p.221).

A razão pela qual Habermas considera que o cosmopolitismo reconstruído discursivamente não incorre em uma moralização direta da política (ainda que mantenha uma vinculação com o universalismo moral, como acusam tanto o realismo político como o relativismo moral) consiste no fato de que a democracia cosmopolita se manifesta no aprimoramento de instituições políticas e jurídicas, ou seja, na reformulação da ONU, do Tribunal de Haia e na formação de uma cidadania e esfera pública mundial. Não obstante, o adversário do cosmopolitismo pode lembrar que tanto a política quanto o direito podem introduzir a moral universal de modo disfarçado na forma de leis que devem ser obrigatórias tanto para os estados membros como para os indivíduos, como ocorre atualmente com a política de intervenção humanitária em estados soberanos acusados de violar os direitos humanos, na medida em que direitos humanos provêm da positivação de normas morais. E, como consequência da moralização da política mediante uma política cosmopolita de proteção de direitos humanos, as organizações cosmopolitas assumiriam uma função policial, o que implicaria criminalizar os inimigos (sejam estados ou agentes do estado) acusados de violar os direitos humanos: os crimes de guerra. Por isso, Habermas precisa mostrar que direitos humanos são direitos genuínos e não simplesmente direitos morais em virtude do fato de ocuparem um papel intermediário entre direito e moral, bem como que as organizações cosmopolitas devem incorporar uma função semelhante ao do estado democrático de direito, o qual aplica de modo procedimental as normas jurídicas.

\section{A reconstrução discursiva do cosmopolitismo}

\footnotetext{
${ }^{2}$ Habermas aduz outros autores e ideias próprios do relativismo moral na argumentação contra Carl Schmitt, mas os relaciona com os argumentos do realismo político schmittiano.
} 
Desde o término da II Guerra Mundial, que as relações internacionais haviam sido caracterizadas pela Guerra Fria entre as superpotências nucleares; neste quadro, as superpotências bloqueavam reciprocamente qualquer intervenção da ONU na pacificação dos conflitos, bem como no combate das violações dos direitos humanos e, ao contrário, fomentavam conflitos ideológicos no âmbito dos estados periféricos. Contudo, uma série de acontecimentos históricos, no final do século, modificou significativamente as relações internacionais: (1) a queda do Muro de Berlin, em 1989, seguida pelo início do processo de unificação alemã, pelo fim dos regimes comunistas do Leste Europeu com a consequente extinção do Pacto de Varsóvia; ao mesmo tempo, (2) o fenômeno da globalização se intensificou e fomentou uma alteração na sociedade civil, pois, na economia, possibilitou o aumento do livre intercâmbio de mercadorias, e, nas relações sociais, a internet e as redes sociais fomentaram novas e mais amplas formas de comunicação entre os indivíduos, que contribuíram ambiguamente tanto para a manipulação política e econômica, quanto para o aparecimento de formas de comunicação diretas e isentas dominação; além disso, (3) novos blocos se desenvolveram, como a União Europeia e o MERCOSUL, os quais procuravam uma integração econômica, jurídica e até política que flexibilizava a soberania dos estados nacionais. Por isso, a nova ordem internacional, que surgia no final do século XX, abria a possibilidade de pensar a retomada do cosmopolitismo mediante a reformulação das instituições supraestatais já preexistentes.

Como consequência desta nova ordem internacional houve uma modificação no conceito de guerra, como se manifestou pela primeira vez na Guerra do Golfo (1990-91), motivada pela invasão do Kuwait pelo Iraque de Saddam Hussein, a qual, longe de refletir a disputa ideológica entre capitalismo e comunismo e esbarrar no bloqueio mútuo das grandes potências, membros permanentes do Conselho de Segurança da ONU, contou com a autorização da Resolução 678 do Conselho de Segurança para a organização de uma força multinacional de intervenção militar. Contudo, embora os defensores do cosmopolitismo tenham saudado alguns aspectos da atuação da ONU, como a adoção da zona de exclusão aérea ao Norte e ao Sul do Iraque para proteger minorias ameaçadas por seu próprio governo (Resolução 688, de 1991) (HABERMAS, 1997, p.212), a verdade é que, em linha geral, a ONU limitou a atuação da força internacional, já que as sucessivas resoluções da ONU sobre o conflito visavam justamente restabelecer a soberania do Kuwait, um de seus estados membros, e se limitou a autorizar a expulsão dos invasores, mas não a intervenção no próprio Iraque. Posteriormente, o conflito na antiga Iugoslávia também introduziu um fenômeno novo, pois o Tribunal de Haia julgou os acusados dos crimes de guerra, embora, também tenha recuado logo em seguida e, atualmente, o julgamento dos crimes de guerra cometidos pelos nazistas e 
pelos líderes da antiga Iugoslávia, representam praticamente uma exceção. No final, estes organismos internacionais acabaram por retornar a sua política de preservar a soberania dos estados nacionais e nunca chegaram a constituir uma organização supraestatal com poder coativo, embora o modelo de uma coalizão de forças multinacionais para proteger os direitos humanos dos cidadãos contra o seu próprio governo se multiplicou a sua revelia, como ocorreu a propósito da operação de limpeza étnica promovida pelo governo da Sérvia na província do Kosovo em 1999, pois, como se tratava de um conflito interno dentro de um estado soberano, não contou com a autorização do Conselho de Segurança da ONU, mas a intervenção militar multinacional foi promovida pela OTAN. Com mesmo caráter limitado ocorreram as intervenções de forças multinacionais no Afeganistão, no Iraque, a Primavera Árabe, o conflito na Síria e a Guerra contra o Estado Islâmico. Contudo, justamente por isso, estas guerras alimentaram as críticas dos realistas políticos de que a política dos direitos humanos mascaram hipocritamente os interesses geopolíticos e econômicos das grandes potências e dos relativistas morais de que a política de intervenções humanitárias representa a imposição da moral universalista do ocidente contra outras culturas. Consequentemente, não é fruto do acaso que Habermas tenha escrito um artigo sobre o cosmopolitismo e a política de direitos humanos, bem como uma resposta às objeções renovadas pelo realismo político schmittiano mesclado com o relativismo moral.

A reconstrução habermasiana do cosmopolitismo propõe uma reformulação da estrutura política dos organismos internacionais já existentes segundo o modelo das constituições nacionais vigentes nos estados democráticos de direito e outras organizações supranacionais como a União Europeia, o que demanda duas observações: (1) a teoria discursiva de Habermas estabelece que são os próprios afetados que devem decidir, com base unicamente da força do melhor argumento, como devem ser as normas que entrarão em vigor, neste sentido, não compete ao filósofo normatizar o modelo político, mas apenas o de apresentar a sua contribuição para a reflexão sobre o tema; além do mais, (2) como Habermas considera que não há um exemplo de organização cosmopolita que sirva de paradigma, ele afirma que o modelo do estado democrático de direito pode servir como uma alternativa preliminar a qual deve ser aprimorada pelo esforço de imaginação institucional dos participantes, embora se possa observar também a influência da estrutura política dos Estados Unidos e da União Europeia em sua proposta.

Baseando-se no modelo do estado democrático de direito, a organização cosmopolita deveria possuir três poderes:

$\mathrm{O}$ poder legislativo competiria à Assembleia Geral da ONU, contudo, em lugar da sua composição atual formada por representantes dos governos dos estados membros, ela deveria ser dividida em duas câmaras, semelhante ao modelo americano em que a Câmara de Deputados representa 
os cidadãos enquanto o Senado representa o pacto federativo, ou seja, os estados membros. Neste sentido, Habermas propõe que uma câmara seja formada, como ocorre atualmente, pelos representantes dos governos dos estados membros, mas a outra câmara deveria ser composta por representantes dos cidadãos de cada um destes estados. Como, entretanto, a maioria dos estados membros não possui a estrutura do estado democrático de direito, seja porque as relações de poder são muito fracas por causa de guerras civis ou porque são demasiado fortes em virtude de ditaduras, etc., então, a resistência destes estados em escolher democraticamente os representantes entre os seus cidadãos implicaria que a Assembleia Geral deveria determinar uma organização não-governamental para representá-los temporariamente (HABERMAS, 1997, p.218).

O poder judiciário seria exercido pelo Tribunal Internacional de Justiça de Haia, o qual não dispunha da competência de ditar sentenças obrigatórias com poder coativo nem para os estados nacionais e muito menos se estender para os conflitos entre os indivíduos e seus respectivos governos, mas se limitava a fazer a arbitragem entre os estados. Portanto, as competências do Tribunal de Haia deveriam ser ampliadas tanto no sentido de poder ditar sentenças obrigatórias para os estados membros com base na legislação estabelecida pela Assembleia Geral, como ocorre com os atuais tribunais constitucionais, quanto na formação de uma justiça penal internacional capaz de julgar regularmente as violações dos direitos e não apenas em casos de exceção, como nos crimes de guerra (HABERMAS, 1997, p.219).

Por fim, o poder executivo deveria ser exercido pelo Conselho de Segurança da ONU. Ao contrário da Assembleia Geral que foi constituída de maneira igualitária, o Conselho de Segurança foi elaborado para reproduzir as relações fáticas de poder no mundo, por isso, as 5 maiores potências dispõe de acento permanente e poder de veto. Contudo, mesmo que este princípio fosse mantido atualmente, a sua composição teria caducado e precisaria ser alterada em função das mudanças nas relações de poder no mundo, uma vez que, não somente estados nacionais como Alemanha e Japão, derrotados na II Guerra Mundial, voltaram a ter projeção mundial, mas organizações supranacionais como a União Europeia passaram a ter um papel no jogo de poder mundial. Não obstante, como Habermas considera que o Conselho de Segurança deve exercer a função executiva da organização cosmopolita, então, não basta um simples remendo, mas ele deve ser profundamente reformulado para um modelo semelhante ao do Conselho de Ministros da União Europeia, formado por representantes de todos os estados membros cujo número varia em função de sua população e no qual o poder de veto dos membros permanentes do atual Conselho de Segurança da ONU é substituído pela regra da maioria. Além do mais, o Conselho de Segurança não deveria simplesmente emitir resoluções cuja observância depende da vontade dos governos ou cuja 
implementação está sujeita ao auxílio da força militar de cada um dos estados membros, mas deveria possuir uma força militar própria capaz de exercer a função de polícia (HABERMAS, 1997, p.219).

\title{
Moralização ou criminalização da política internacional?
}

Em seu principal livro destinado a esclarecer o significado do fenômeno político, $O$ conceito do político, Carl Schmitt concebe a sociedade moderna dividida em várias esferas de valor separadas, as quais se tornaram especializadas em um conjunto binário de valores concorrentes com os demais valores das outras esferas. Consequentemente, Carl Schmitt considera que cada esfera social, como a religião, a economia, o direito, a estética, a ciência, a moral e o político, possui características específicas que a distingue de outras esferas, uma vez que cada uma delas é regida por um par de valores próprios. Neste sentido, por exemplo, o conceito do econômico é regido pelo par de valores útil/prejudicial, do estético pela beleza/feiura, enquanto da moral pelo bem/mal, mas o fenômeno do político é determinado pelo par de valores amigo/inimigo (SCHMITT, 1979, p.23). Estes valores são autônomos entre si de modo que o amigo ou inimigo políticos não têm porque ser considerados úteis ou prejudiciais, belos ou feios, bons ou maus, pois o que permite determinar a diferenciação entre amigos e inimigos é a intensidade do grau de vínculo ou separação, de associação ou dissociação da relação entre eles. Por isso, o inimigo político não pode ser confundido com o mau, com o feio ou com o concorrente nos negócios, ao contrário, o inimigo pode até mesmo ser um bom parceiro econômico, mas o que caracteriza o inimigo é simplesmente ser:

\begin{abstract}
o outro, o estranho, porque é suficiente que se constitua em algo distinto e diferente em sentido existencial de tal modo que, em casos extremos, o conflito com ele seja possível e que estes conflitos não possam ser resolvidos por um regimento geral ou pela arbitragem imparcial de um terceiro nãoenvolvido (SCHMITT, 1979, p.27).
\end{abstract}

Deste modo, a relação amigo/inimigo não representa uma relação privada, pois o inimigo não é apenas o adversário com quem se compete ou uma pessoa que se odeia por motivos emocionais (SCHMITT, 1979, p.29), mas, para que se caracterize um fenômeno como político, tem que ocorrer o que Carl Schmitt denomina o "caso decisivo" (Ernstfalles), ou seja, os envolvidos tem que estar dispostos a ir à guerra um com o outro, por isto, o fenômeno do político se manifesta fundamentalmente na modernidade através do estado, pois, seguindo uma interpretação hobbesiana, ele considera que o estado moderno conseguiu deter o monopólio do exercício da violência legal dentro do seu território, por isso, a guerra somente é possível entre estados soberanos, e consequentemente, deve-se diferenciar a 
política da polícia, porque, embora ambas as palavras derivem do grego polis, a política demanda a possibilidade real de instauração do conflito, enquanto, se o outro se submete pacificamente as determinações da autoridade e não está disposto a se envolver em combate, trata-se simplesmente de um caso de polícia (SCHMITT, 1979, p.10). Portanto, o fenômeno do político se identifica com o estatal (SCHMITT, 1979, p.10) de tal modo que em um mundo totalmente pacificado, onde não houvesse mais a possibilidade do combate, não haveria a relação amigo/inimigo e, consequentemente, também não haveria política (SCHMITT, 1979, p.35), mas tão somente polícia.

Como a política exige a possibilidade real do inimigo, então, da definição do conceito do político segue-se a consequência lógica de que deve existir sempre uma pluralidade de estados. Contudo, caso os diferentes povos da terra fossem reunidos em um império mundial que conseguisse exercer o monopólio da violência legal e afastasse inclusive a possibilidade da guerra civil, então não haveria mais a relação amigo/inimigo e, consequentemente, poderia existir uma civilização, uma cultural, etc., mas a política deixaria de existir (SCHMITT, 1979, p.54). Portanto, a humanidade como um todo não pode realizar uma guerra simplesmente porque ela não tem inimigos no planeta Terra e o conceito de humanidade suprime o conceito de inimigo, uma vez que o fato de se tornar inimigo não o exclui da condição humana (SCHMITT, 1979, p.54). Não obstante, cada vez mais se torna comum que um estado combata o seu inimigo em nome da humanidade, mas isto não significa que esta guerra seja uma guerra empreendida pela humanidade. O que ocorre, neste caso, é um uso ideológico do conceito de humanidade em que um ou ambos os lados da contenda se apropria de um conceito universal para se identificar com ele negando-o à outra parte, do mesmo modo que se pode fazer um uso ideológico da paz, da liberdade, da justiça, da igualdade, etc. É, neste sentido, Carl Schmitt faz a sua famosa paráfrase de Proudhon: "o que fala em nome da humanidade, quer enganar" (SCHMITT, 1979, p.55).

A partir do exposto, Carl Schmitt questiona a legitimidade do cosmopolitismo uma vez que a Sociedade de Nações que surgiu depois do Tratado de Paz de Versalhes $^{3}$, de 1919, que puseram fim a I Guerra Mundial, é uma construção contraditória, porque não é uma organização universal e nem mesmo internacional, a qual supostamente estabeleceria uma sociedade universal despolitizada em virtude da ausência da relação amigo/inimigo, como a Terceira Internacional Socialista pretende ser, mas uma organização meramente interestatal uma vez que não somente pressupõe a existência dos estados como, inclusive, legitima a sua existência e o seu status quo, mas principalmente, porque:

${ }^{3}$ Na verdade, Carl Schmitt se refere a eles sistematicamente como "Tratado de Paz de Paris". 
A Sociedade das Nações de Genebra não elimina a possibilidade das guerras, assim como também não elimina os estados. Ela introduz novas possibilidades de guerra, permite guerras, fomenta guerras de coalizão e elimina uma série de restrições à guerra pelo fato de que legitima e sanciona determinadas guerras (SCHMITT, 1979, p.57).

Segundo Habermas, antes da II Guerra Mundial, Carl Schmitt já alertara sobre a necessidade de não se discriminar as guerras como forma de limitar os conflitos e evitar a guerra total, mas ainda não havia prevenido sobre as consequências desastrosas do universalismo moral (HABERMAS, 1997, p.228). Contudo, depois da Guerra ele tem dificuldades de manter a coerência de sua teoria porque $\mathrm{o}$ advento da guerra total e o desenvolvimento de instituições cosmopolitas que fomentaram a proteção dos direitos humanos e democracia colocam em cheque a sua tese de identificação do político com o estatal baseado na bivalência amigo/inimigo. Por isso, ele foi obrigado a reformular o seu ponto de vista em três aspectos: (1) inicialmente tentou negar a importância dos crimes de guerra cometidos pelos nazistas e o seu julgamento, como uma atrocidade excepcional e não como a regra vigente no pós-guerra; (2) em seguida, inverteu o ônus da prova, pois, enquanto Habermas considera o desenvolvimento do cosmopolitismo como uma consequência da guerra total, para Carl Schmitt é o universalismo moral, com sua exigência de proteção dos direitos humanos e fomento da democracia, que gerou instituições cosmopolitas as quais passaram a atuar como polícia, criminalizando o adversário e impulsionando as guerras além de qualquer limite, tornando-as guerras totais; (3) por fim, pretendeu salvar a própria teoria na medida em que considerou que as guerras totais representavam não somente um aumento quantitativo, mas um salto qualitativo no seu conceito do político, pois nelas não se negava, mas se percebia um novo nível da relação amigo/inimigo (HABERMAS, 1997, p.228-9).

É verdade que no II Corolário, intitulado "Sobre a relação entre os conceitos de guerra e inimigo", incorporado a $O$ conceito do político em 1938, Carl Schmitt introduz o conceito de guerra total ${ }^{4}$ e mostra como ela surgiu em função da continuidade das ações tomadas pelas potencias vencedoras sobre as nações vencidas depois do Tratado de Paz de Versalhes, especialmente o sistema de pactos políticos adotados pela Sociedade de Nações, localizada em Genebra, que taxativamente definia a agressão e o agressor de modo que: "a estrutura conceitual do Direito Internacional se tornou progressivamente criminalista e orientada para o Direito Penal" (SCHMITT, 1979, p.103). Deste modo, o agressor no Direito Internacional foi se convertendo gradativamente no criminoso do Direito

\footnotetext{
${ }^{4}$ Cuja paternidade é muitas vezes atribuída erroneamente ao discurso pronunciado em 18 de fevereiro de 1943pelo ministro da propaganda nazista Joseph Goebbels.
} 
Penal porque a sua agressão passou a ser interpretada como um crime: "segundo o Direito Internacional de Genebra surgido no pós-guerra, [a guerra de agressão] deve ser convertida em um fato criminal e o inimigo tem que ser convertido em um bandido" (SCHMITT, 1979, p.104).

Também é verdade que, depois da II Guerra Mundial, Carl Schmitt muda a perspectiva de sua teoria, pois, no "Prefácio", introduzido para a edição de 1963, embora continue insistindo que a culpa é da criminalização do inimigo promovida pelas novas relações desenvolvidas no direito interestatal (SCHMITT, 1979, p.11-2), reconhece o caráter histórico das concepções políticas e que o seu conceito do político foi desenvolvido para o que ele denominou de jus publicum Europaeum vigente na Europa como reação às guerras religiosas fruto da cisão do Cristianismo, no início da Modernidade, em que o estado soberano surgiu como figura neutra capaz de pacificar internamente os conflitos religiosos, eliminando a inimizade entre as religiões e impondo o poder de polícia sobre os seus habitantes, mas cuja soberania implicou apresentar-se, no plano interestatal, como agente político, por isso, fazia sentido afirmar que houve um tempo em que o conceito do político se identificou com o conceito do estado. Neste quadro "clássico" havia diferenças claras entre militar e civil, neutralidade e nãoneutralidade, além disso, reconhecia-se a soberania dos outros estados, o seu direito à guerra, e a sua condição como inimigo justo, o que permitia distinguir explicitamente a guerra e a paz. Este quadro clássico de limitação das guerras contribuía muito mais para o humanismo, pois havia mais ações corretas, do que a situação atual de repudiar a guerra limitada, designando-a reacionária ou criminosa, pois isto desata, na forma de guerras justas, inimizades de raça ou de classes sociais incapazes ou sem interesse em reconhecer as diferenças entre inimigo e criminoso (SCHMITT, 1979, p.12).

Entretanto, Habermas interpreta as ponderações de Carl Schmitt de maneira diferente, pois, baseado em uma breve referência que se encontra em seu Glossarium, considera que Carl Schmitt atribuiu ao universalismo moral do projeto cosmopolita kantiano o panintervencionismo disfarçado na atuação dos organismos internacionais que em nome da proteção dos direitos humanos e da democracia que teria como efeito indesejado de pancriminalização do adversário. Por isso, ele considera necessário responder a duas questões que estariam implícitas no pensamento schmittiano: em primeiro lugar, na medida em que os direitos humanos provêm da moral, a política de direitos humanos conduz à moralização da política internacional, fazendo com que as guerras apareçam como ações policiais; em segundo lugar, uma vez que a moral usa o código binário bem/mal, a moralização da política internacional transforma o inimigo em um criminoso, gerando formas mais brutais de desumanidade, visto que as guerras mais terríveis passam a ser realizadas em nome da paz (HABERMAS, 1997, p.220). Portanto, Habermas considera necessário, na sua resposta à Carl Schmitt, mostrar (1) que os direitos humanos não são 
direitos morais e; (2) que a democracia cosmopolita é única capaz de aplicar os direitos humanos sem incorrer na moralização da política internacional.

\section{0 universalismo moral e a política de direitos humanos}

Os direitos humanos têm sido confundidos com direitos morais por três razões principais: (1) do ponto de vista da história, os direitos humanos remetem à luta empreendida durante a Modernidade contra o absolutismo monárquico, tanto pelo liberalismo, que considerava que os direitos do homem são fundamentados na própria natureza humana, quanto pelo republicanismo, o qual argumentava que a vontade soberana do povo é a única que não pode ser injusta contra ninguém, por isso, deveria legitimar os direitos do homem, como eram expressos no pensamento de John Locke e Jean-Jaques Rousseau respectivamente, uma vez que o britânico considerava que o direito à vida, à liberdade, e à propriedade privada provém da propriedade que o indivíduo possui sobre seu próprio corpo, o qual teria que renunciar simplesmente ao direito natural ao exercício da violência sobre o outro segundo a lei de talião, para ingressar no estado civil, o que significava que, a partir deste momento, o estado se tornava o detentor do monopólio da violência legal, enquanto o genebrino entendia que o indivíduo deveria renunciar inteiramente aos seus bens e direitos para a vontade geral ao ingressar no estado civil, mas, posteriormente, deveria recuperá-los integralmente porque a vontade geral é a única que não pode cometer injustiças contra ninguém. Esta vitória dos ideais liberais e republicanos acabou refletida na Constituição da Virgínia e na Segunda Carta da Filadélfia (Declaração de Independência dos EUA), de 1776, bem como na Declaração dos Direitos do Homem e do Cidadão da Revolução Francesa, de 1789 (HABERMAS, 1997, p.221); (2) do ponto de vista conceitual, a reminiscência metafísica e teológica da separação entre o direito natural (de origem divina) e o direito positivo (instituído pelo príncipe) vigente no Cristianismo medieval acabou contaminando o direito natural racional moderno e provocando a confusão conceitual de que a moral, fundamentada agora na razão, deveria preceder e tão somente ser positivada pelo direito positivo instituído pelo soberano, o que ocasionava duas concepções equivocadas acerca dos direitos humanos, pois os direitos humanos, devido a sua origem na moral, ou ocupavam um papel intermediário entre a moral e o direito positivo, ou eles simplesmente resultavam da positivação de normas morais (HABERMAS, 1997, p.221-2); (3) por fim, dada a estrutura que o ordenamento jurídico adquiriu na Contemporaneidade, em virtude da Revolução Americana e Francesa, no final do século XVIII, no qual se distingue entre normas constitucionais, representadas na constituição, e legislação ordinária, expressa nos códigos de direito, bem como que, na própria constituição, algumas normas adquiriram o status privilegiado de cláusulas pétreas que não podem ser 
modificadas em nenhuma hipótese na vigência da ordem constitucional, passando a ter a configuração de direitos fundamentais, fomentou-se a concepção de que estes direitos fundamentais em geral possuíam um status suprapositivo, já que estavam indisponíveis para o legislador e para a própria soberania popular. Embora o conceito de direitos fundamentais tenha começado com os direitos do homem, eles foram se ampliando ao longo do tempo, incluindo também direitos sociais, políticos e até ecológicos, mas os atuais direitos humanos ainda dispõem de um status privilegiado inclusive entre o elenco de direitos fundamentais (HABERMAS, 1997, p.223).

Contudo, Habermas considera que os direitos humanos são direitos como quaisquer outros por causa de sua estrutura, pois, enquanto na moral, a autonomia é constituída por uma única peça na medida em que o agente deve agir motivado pelo reconhecimento da validade da própria norma, ou, na linguagem kantiana, deve agir por dever, no direito, a autonomia se divide em duas, como se fossem duas caras inseparáveis da mesma moeda, a autonomia privada, que permite aos agentes seguir a norma jurídica como um fato social com base no motivo que quiser (agir conforme o dever), como o autointeresse racional ou o medo da coação, e a autonomia pública que permite que ele obedeça a lei por respeito à própria lei, na medida em que o cidadão se reconhece, ainda que virtualmente, como seu autor pelo exercício da soberania popular, porque as normas jurídicas são dotadas de faticidade e validade, isso significa que elas podem ser impostas como fatos sociais instituídos por organizações dotadas de poder coercitivo ou ser seguidas pelo reconhecimento de sua legitimidade. Neste sentido, os direitos humanos não possuem a estrutura da moral, mas aquela dos direitos em geral, pois, tal como as outras normas jurídicas, possuem faticidade e validade já que tanto podem ser impostas como fatos sociais ou como normas que merecem reconhecimento, assim como os indivíduos podem obedecê-los segundo a sua autonomia privada, escolhendo os motivos pelo qual desejam segui-los, ou como cidadãos mediante a sua autonomia pública, por respeito à lei (HABERMAS, 1994, p.42-3).

Esta mesma tensão interna entre faticidade e validade se mostra também no sistema de direitos e no processo legislativo de produção de normas jurídicas. Neste último caso, os autores das normas, que segundo o princípio da soberania popular são os próprios cidadãos, ainda que, na prática, esta soberania seja exercida por órgãos legislativos representativos, também podem produzir as normas jurídicas segundo a sua autonomia privada ou a sua autonomia pública, pois, se adotassem o ponto de vista moral no processo legislativo, para o qual somente há uma única forma de autonomia, implicaria exigir que as minorias derrotadas, ainda por cima, seriam obrigadas a obedecer as normas, com as quais não concordam, por respeito à própria lei. Contudo, justamente esta estrutura bipartida do direito permite que as minorias derrotadas tenham que seguir a norma como um 
fato social imposto coercitivamente, mas possam apresentar novas razões no futuro que sejam capazes de formar novas maiorias capazes de modificá-la. Portanto, toda norma jurídica, incluindo os direitos humanos, pode ser instituída ou derrogada pelo legislador.

O que os direitos humanos compartilham, embora com a sua própria especificidade, com as normas morais e, por isso, gerou a confusão de que direitos humanos são direitos morais, é devido ao fato de que ambos possuem uma pretensão de validade universal, já que, assim como as normas morais, os direitos humanos, valem para todos os seres humanos em geral, independentemente de sua relação com um estado específico (HABERMAS, 1997, p.222). Segundo Habermas, a causa encontra-se no modo de fundamentação dos direitos humanos. De acordo com a teoria comunicativa, as normas, sejam morais ou jurídicas, devem ser aprovadas em discursos racionais regidos pelo princípio do discurso D. As normas jurídicas são fundamentadas em discursos jurídicos, regidos pelo princípio do direito, os quais institucionalizam as questões pragmáticas, aquelas que dizem respeito aos fins e interesses coletivos de ação, aprovadas em discursos pragmáticos, as questões éticas que se referem às concepções do bem ou de vida boa do indivíduo ou da comunidade, avaliadas em discursos éticos, as questões morais, que podem ser do interesse simétrico de todos os afetados, analisadas em discursos morais submetidos ao princípio de universalização $U$, segundo o qual são válidas as normas que forem aprovadas por todos os afetados por sua entrada em vigor, além das negociações realizadas sob condições equitativas. Para Habermas, a decomposição do ethos das sociedades tradicionais, no início da Modernidade, provocou a dissociação entre ética e moral, pois permitiu que se distinguisse entre as concepções do bem e de vida boa que são relativas para cada indivíduo ou para cada comunidade e medidas por valores que podem ser hierarquizados segundo uma ordem de preferências, das questões morais, as quais devem ser avaliadas racionalmente segundo o critério de sua retidão e, uma vez aprovadas por todos os afetados por sua entrada em vigor, o que inclui toda a humanidade, tornam-se universalmente válidas (HABERMAS, 1994, p.197-201). No entanto, na fundamentação dos direitos humanos não entram questões pragmáticas, éticas, ou o resultado das negociações imparciais, mas apenas as argumentações morais e, por isso, apresentam também uma pretensão de validade universal (HABERMAS, 1997, p.223).

\section{Democracia cosmopolita}

O conceito do político de Carl Schmitt sofreu muitas modificações e ampliações ao longo do tempo. A publicação inicial é de 1927, mas o texto base, utilizado atualmente, provém de uma reformulação de 1932, ademais foram incluídos corolários em 1931 e 1938 e um novo prefácio em 1963. 
Isto indica que a obra reflete momentos diferentes tanto da história contemporânea como da evolução do pensamento do autor. Habermas considera que a intenção inicial de Carl Schmitt era defender o retorno ao jus publicum Europaeum (HABERMAS, 1994, p.227), que foi desenhado na filosofia hobbesiana e vigorou na Europa depois dos Tratados de Paz da Vestfália até a I Guerra Mundial, durante o qual os estados soberanos detinham o monopólio da violência legal que lhes permitia garantir a paz e segurança para os seus súditos dentro de suas fronteiras, ainda que ao preço de preservar o estado de natureza de guerra de todos contra todos no exterior; mas isto gerou o equilíbrio entre as potências europeias, devido a um rígido controle recíproco, e conduziu a guerra para limites civilizados, porque os governos tinham que realizar guerras prudentes, com objetivos específicos e definir claramente o começo e o fim das hostilidades, para evitar a suspeita das outras potências de que um estado pretendia alcançar a hegemonia continental, o que provocaria uma aliança de todos os demais estados contra o agressor. Esta condição permitiria recolocar a guerra dentro dos limites tecnológicos, militares e ideológicos, que foram perdidos durante a I Guerra Mundial, com o uso de armas de destruição em massa, como o gás tóxico, e veículos motorizados, como tanques e aviões, que afetaram a população civil, bem como com a criminalização da guerra e do adversário promovida pelo Tratado de Versalhes e a criação da Sociedade de Nações de 1919. 
Por outro lado, já no II Corolário de 1938, portanto, antes mesmo da Segunda Guerra Mundial ${ }^{5}$, Carl Schmitt, acentua a sua crítica ao objetivo de eliminar todas as guerras por meio de organizações interestatais, entre as quais se destacava a Sociedade das Nações, uma vez que isto conduziu à criminalização do estado de guerra e dos atos perpetrados por indivíduos durante ela, o que causou justamente o efeito oposto ao pretendido, pois levou à substituição das guerras limitadas pela guerra total (SCHMITT, 1979, p.59-60). Neste sentido, Habermas afirma que, para Carl Schmitt, a criminalização da guerra no âmbito do direito internacional, realizada pelas organizações cosmopolitas, gerou a guerra total; no entanto, Habermas pensa que ocorreu justamente o contrário, pois, o cosmopolitismo representou um esforço para controlar a guerra total que surgiu como decorrência do estado de natureza entre os estados; além disso, ele também considera que a degeneração da guerra pode ser evitada de forma mais eficiente por meio da regulamentação destes organismos cosmopolitas do que pelos efeitos imprevisíveis do retorno ao equilíbrio das potências do jus publicum Europaeum (HABERMAS, 1997, p.226).

Além do mais, Habermas ridiculariza o argumento de Carl Schmitt, segundo o qual a substituição do jus publicum Europaeum pela nova ordem cosmopolita internacional, teria graves consequências também para a paz e a segurança internas dos estados, porque o estado detentor do monopólio da violência legal só consegue manter a ordem, regenerando a sua substância política contra os inimigos externos, por isso, o controle das guerras externas faria ressurgir a relação amigo/inimigo entre os membros do estado, desatando a guerra civil. Segundo Habermas, a perspectiva schmittiana de apresentar uma assimetria entre a relação política pacificada internamente e beligerante externamente é inconsequente porque Carl Schmitt entende a paz dentro do estado também segundo o modelo da relação amigo/inimigo, portanto, como o resultado do enfrentamento latente entre os detentores do poder político e os seus inimigos internos, e, como os donos do poder dispõem das instituições do estado, então, eles mantém os seus adversários sob controle mediante o uso da ameaça velada de criminalizar os seus adversários, condenando-os como subversivos ou terroristas em uma guerra civil, mas, isto constitui uma caracterização moral do adversário e, portanto, implica a introdução de categorias morais no âmbito do político. Mas se a pacificação no plano interno é obtida pela ameaça constante de criminalização do adversário e, por conseguinte, pela moralização da política, então, resulta incoerente que Carl Schmitt critique a mesma estratégia de criminalização do adversário nas relações interestatais

\footnotetext{
${ }^{5}$ Somente no "Prefácio de 1963", ele decreta o fim do jus publicum Europaeum e considera que já não é mais possível retornar ao status quo anterior, vigente a partir dos Tratados da Vestfália porque o Tratado de Versalhes representa a inauguração de uma nova época, marcada pela perda da soberania dos estados.
} 
quando ela é realizada pela organização cosmopolita contra um estado acusado de violar os direitos da humanidade (HABERMAS, 1997, p.234).

Segundo Habermas, Carl Schmitt acusou o universalismo moral kantiano de servir como fundamento para esta ideologia de controle das guerras empreendidas pelas organizações cosmopolitas em nome da humanidade, o que conduziria a uma moralização da política internacional em defesa dos direitos humanos (HABERMAS, 1997, p.220). Contudo, deve-se recordar que o argumento principal de Carl Schmitt não consiste propriamente em acusar as instituições cosmopolitas de moralização da guerra na medida em que os valores morais bem/mal são inseridos como critérios para julgar as relações amigo/inimigo, como afirma Habermas, pois, como se demonstrou antes, ele se queixou, na verdade, de que a aplicação do direito penal nas relações internacionais provoca a criminalização da guerra em nome da humanidade. Não obstante, Habermas apresentou uma demonstração indireta de sua afirmação na medida em que Carl Schmitt recordou que as guerras autorizadas pelas organizações cosmopolitas em nome da humanidade correspondem à forma moderna de guerra justa, mas o conceito de justiça implica categorias morais; portanto, se Carl Schmitt critica o humanismo do cosmopolitismo por retomar o conceito de guerra justa significa que na relação amigo/inimigo, os amigos representam o ponto de vista justo da defesa dos ideais da humanidade, enquanto os inimigos representam a perspectiva injusta de violar os princípios humanitários, logo, constitui uma moralização da política internacional (HABERMAS, 1997, p.229). Do mesmo modo, não há referências claras na obra de Carl Schmitt contra a moralização específica dos direitos humanos empreendida pela organização cosmopolita, mas aqui Habermas também apresentou um argumento indireto, pois, na medida em que Carl Schmitt critica as guerras empreendidas em nome da humanidade, isto significa que um estado ou uma aliança de estados se apropria de um conceito universal atribuindo-o para si e negando-o para o seu inimigo, e, ao se autoatribuir a defesa dos valores da humanidade que estão sendo violados pelo oponente, dada a estrutura jurídica da sociedade contemporânea, isto implica necessariamente uma menção aos direitos humanos (HABERMAS, 1997, p.233).

Habermas considera que a crítica de Carl Schmitt goza ainda hoje de grande aceitação porque ele alertou corretamente para a prática de moralização direta da política internacional que efetivamente costuma ocorrer $^{6}$. Este abuso acontece quando uma das partes começa moralizando a ação política segundo os valores do bem e do mal e, depois, criminaliza o

\footnotetext{
6 Além disso, também constitui uma verdade histórica inquestionável que as medidas tomadas a partir do Tratado de Versalhes e a política da guerra contra a guerra empreendida pela Sociedade de Nações, como alertou Carl Schmitt, se constituíram parcialmente em um uso ideológico do conceito de humanidade e, com isso, alimentaram o desenvolvimento de ideologias totalitárias em toda a Europa, preparando o caminho para a II Guerra.
} 
comportamento da outra parte de acordo com os valores lícito/ilícito. A política de garantia dos direitos humanos da organização cosmopolita se transforma em um "fundamentalismo dos direitos humanos" quando converte um conflito entre as partes em uma intervenção legitimada legalmente mediante resoluções que encobertam o enfrentamento militar como se fossem ações policiais. Evidentemente que o alerta de Carl Schmitt ainda continua válido atualmente, como se pode constatar na grave crise dos refugiados da Síria, pois, as ações militares das potencias mundiais para a promoção da reivindicação genuína de defesa dos direitos humanos e da democracia dos sírios contra o seu governo autoritário é contaminada, em grande parte, pelo conflito de interesses econômicos e políticos entre elas ${ }^{7}$.

Contudo, Carl Schmitt considera que a política de defesa dos direitos humanos nas relações internacionais descamba "sempre e necessariamente" (stets und notwendig) em um fundamentalismo dos direitos humanos, pois, a apropriação dos ideais da humanidade é uma ideologia em que uma parte traveste os seus valores particulares em universais e os nega ao seu adversário, pois, "aquele que fala em nome da humanidade, quer enganar", além disso, "a humanidade não pode fazer guerra", porque toda guerra seria sempre de uma parte contra outra, e nenhuma delas representaria, portanto, toda a humanidade, logo, a referência política à humanidade incorreria sempre em um fundamentalismo dos direitos humanos, no qual existe uma moralização direta da política, uma vez que uma parte assume a defesa dos valores da humanidade enquanto o adversário é condenado por agir contra os valores da humanidade, transformando o conflito em uma guerra do bem contra o mal. Isto ocorre porque, para Carl Schmitt, os direitos humanos são direitos morais e as relações internacionais são caracterizadas pelo conflito entre estados soberanos que se relacionam entre si com base nos valores amigo/inimigo (HABERMAS, 1997, p.235-6).

Evidentemente que, mantida a situação atual, em que o estado de natureza entre os estados apenas começa a ser superado por acordos internacionais, bem como a composição das Nações Unidas, dificilmente o fundamentalismo dos direitos humanos poderá ser evitado. Contudo, Habermas considera que a solução não pode ser encontrada no retorno ao jus publicum Europaeum, o que, aliás, o próprio Carl Schmitt reconheceu não ser mais possível, no "Prefácio" de 1963, mas, no aprimoramento da democracia cosmopolita. Pois, os direitos humanos não são direitos morais e, portanto, a sua aplicação não significa a moralização direta da política, pois, na medida em que as normas morais são positivadas no ordenamento jurídico, elas passam a dispor das mesmas características de todo e qualquer direito, além disso, somente a reestruturação das organizações mundiais

\footnotetext{
${ }^{7}$ De um lado, a Europa e os EUA querem a destituição do governo de Assad, o que permitiria a construção de um oleoduto que conduziria o petróleo do Oriente Médio para a Europa, enquanto a Rússia deseja a continuidade do governo Assad justamente para manter o seu monopólio no comércio de petróleo com a Europa.
} 
pode gerar uma democracia cosmopolita na qual os direitos humanos sejam institucionalizados no plano internacional de modo semelhante ao modo como o são dentro do estado de direito, ou seja, por autoridades competentes, seguindo procedimentos estabelecidos estritamente na legislação cosmopolita, que julgam de maneira imparcial e dispõe de um poder coativo próprio isento da manipulação dos interesses das partes (HABERMAS, 1997, p.236).

\section{Referências bibliográficas:}

BAYNES, K. "Democracy and the Rechtsstaats: Habermas's Faktizität und Geltung". In: WHITE, S. Cambridge companion to Habermas. Cambridge, Cambridge Univ. Press, 201-32 p., 1995.

BOHMAN, J. "Complexity, pluralism, and the constitutional state: On Habermas's Faktizität und Geltung". Law and Society Review. /s.1./, 28(4):897-930, 1994.

HABERMAS, J. Faktizität und Geltung. Frankfurt am Main: Suhrkamp Verlag, 1994.

_Die Einbeziehung des Anderen. Studien zur politischen Theorie. 2.Aufl., Frankfurt am Main: Suhrkamp Verlag, 1997.

MARTINS, C. A. \& POKER, G. (org.) O pensamento de Habermas em questão. Marília: Oficina Universitária UNESP, 2008.

ROUSSEAU, J.-J. Du contrat social. Paris: Gallimard, 2002.

SCHMITT, C. Der Begriff des Politischen. Duncker und Hunblod: Berlin, 1979.

_Glossarium: Aufzeichnungen der Jahre 1947-1951. Duncker und Hunblod: Berlin, 1991.

VELASCO, J. C. La teoría discursiva del derecho. Madrid: Centro de Estudios Políticos y Constitucionales, 2000. 